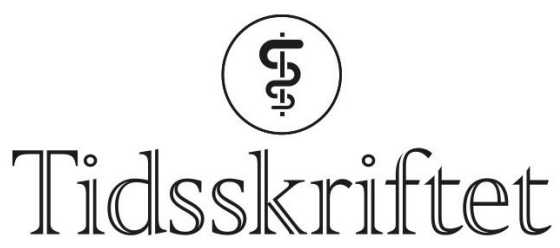

DEN NORSKE LEGEFORENING

\title{
Når Saturn står i Jomfruen
}

MINILEDER

\section{ARE BREAN}

Sjefredaktør

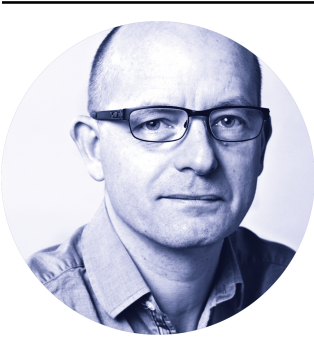

Den 6. mars 2019 må stjerner og planeter ha stått i en usedvanlig gunstig posisjon. Da ga nemlig Nasjonalt organ for kvalitet i utdanningen (NOKUT) Astrologiskolen Herkules offentlig akkreditering som fagskole. NOKUT er det statlige organet som skal kontrollere kvaliteten på høyere utdanning i Norge.

På astrologiskolens nettsider kan vi lære at helsevesenet er i krise, og at «det er på denne bakgrunn at det også er blitt plass til astrologer». Videre kan vi lære at Saturn i Jomfruen legger forholdene til rette slik at blant annet «effektivisering av helsesektoren kan vokse fram». Og annetsteds at «hvis klientens Måne er i kvadratur til astrologens Mars er det ikke sikkert at de finner tonen like lett, som hvis Månen og Venus var i konjunksjon». Dette mens man i skolens informative artikkel om "astrologimedisin» kan lese at «horoskopet gir den detaljinformasjon som er nødvendig for å anrette en balansert behandlingsstrategi».

Til utdanning i dette grenseløse tøvet får man nå altså støtte fra Statens lånekasse for utdanning. Godkjente fagskoler som denne skal gi kompetanse som kan tas i bruk i arbeidslivet uten ytterligere opplæring, slår fagskoleloven fast. Mens kvakksalverloven er opphevet. Av og til er det uråd å vite om man skal le eller gråte.

Publisert: 8. april 2019. Tidsskr Nor Legeforen. DOI:10.4045/tidsskr.19.07.01

(C) Tidsskrift for Den norske legeforening 2020. Lastet ned fra tidsskriftet.no 